\title{
Akhlak and Academic Ethics: Idealism Among Pragmatism in Community Social Life
}

\author{
Syamsu Nahar', Yusnaili Budianti', Qoriah Elfi Lina Safitri Ro ${ }^{2}$ \\ 1Postgraduate Lecturer at State Islamic University (UIN) North Sumatra, Medan, Indonesia \\ 2Student of State Islamic University (UIN) North Sumatra Medan, Indonesia \\ qarielfi@yahoo.com \\ *Corresponding Author: qarielfi@yahoo.com
}

\begin{abstract}
Basically, in social life in achieving progress it is indicated that a person is able to meet the needs of a social group so that that person can contribute to society. Regardless of the intention of a person, one of the efforts made by the community to obtain education is to get a scholarship so that it gets recognition from the community about their social status. If we look at it in today's society, it seems that this view has started to shift because if we see that the award is more to a degree than from one's knowledge. This has prompted some people to take academic degrees with a path that is not in accordance with the procedure. The procedure that was followed was what damaged the social order and academic ethics. It can be said that this degree was obtained based on the objective, namely degree fever. The academic world is a forum whose process always follows academic ethics through scientific activities. Thus academic ethics is essentially a scientific activity that takes place in higher education which includes universal and developing activities. Higher education institutions must be prepared to accept criticism with mutual respect and not engage in discriminatory activities. Violations committed in academic ethics are something that damages and tarnishes the world of education. In order for these educational values to be implemented optimally, we need a rule that can control the process of implementing education; this is what is called academic ethics. The emphasis on the value of honesty in academic ethics consists of two things, namely in writing scientific papers and completing studies. Therefore, it is demanded that every education actor is systematic and comprehensive and requires commitment from various parties to fix problems in education.
\end{abstract}

Keywords: academic ethics; idealism; pragmatism; academic society

\section{Introduction}

Basically, education is a means for every individual or group of people to develop their knowledge and knowledge in achieving the mission and vision of a group of people. Thus through education, the expected results are that each student has the concepts and basics of education that are organized and most importantly so that students have ethics. Every educational activity, both in conceptualizing educational theories and in operational techniques, must have strong foundations and have guidelines for academic ethics. In order for these educational values to be implemented optimally, we need a rule that can control the process of implementing education; this is what is called academic ethics. Ethics is something that is related to social and cultural values that have become an agreement in a community as norms and rules that are adhered to collectively, this ethic is not always the same in all societies (Amir, 1999: 34).

Talking about academic ethics, this cannot be separated from the participation of the important role of Islamic Education. In this connection, education must be able to foster character through the development of academic values. This means contradicting the concept of social pragmatism and material achievement alone. The values of academic ethics must be held and applied in every academic person ideally in the midst of the challenges of today's pragmatism. Herein lays the important function of academic ethics, which is the study in this article.

Basically, in social life in achieving progress, it is indicated that a person is able to meet the needs of a social group so that that person can contribute to society. Regardless of the intention of a person, one of the efforts made by the community to obtain an education is to get a scholarship so that it gets recognition from the community about their social status. Based on the review from Islam that knowledge is not sufficient for the provision in living life but that person must be accompanied by a height of manners and morals. If we look at it in today's society, it seems that this view has started to shift because if we see that the award is 
more to a degree than from one's knowledge. Some of the titles given to his name give confidence and appear quality in front of the community.

This has prompted some people to take academic degrees with a path that is not in accordance with the procedure. The procedure that was followed was what damaged the social order and academic ethics. It can be said that this degree was obtained based on the objective, namely degree fever. This can be seen during community activity events, if the title is not included it will give a feeling of confusion because the community is afraid that one of the candidates is not qualified. Moreover, also in various community activities such as during the Maulid season of the Prophet and Isra 'and Mi'raj, this will clearly be seen in the flu degree hit in these community activities. Some certain individuals put up improper titles for preachers who were invited to the event which was held whose purpose was to attract the attention of the public. Moreover, some people will try to get a bachelor's degree in a way that is not according to procedures or can be said with intellectual fraud.

When viewed from various sources of media information, there are many acts of academic fraud that have been committed in various academic realms in Indonesia. It can be concluded temporarily that some tertiary institutions in Indonesia have not been able to produce superior and quality human resources. Although basically, academic cheating has certain reasons, it is an offense academic ethics. Actions that violate academic ethics are actions that facilitate all means without going through procedures to achieve the ultimate goals of higher education. To change one's viewpoint, you must not only teach ethics to someone as something separate from the research process. This means that research activities are not related to academic achievement, the most important and urgent thing is how to find solutions to failures. So research activities are activities that are carried out not only during academic activities but also outside academics. But even so, academic ethics must also be upheld because honesty is the most important thing to get results without harming others. The point is the question of mastery of the technique, because with the development of thinking technique mastery must be.

\section{Discussion}

\subsection{Basics of Academic Ethics and Operational Forms}

Adab can be defined as all praiseworthy actions and deeds that become a person's character or habit, thus between adab and morals is something that cannot be separated. Quoting Ibn Qayyim's words that basically adab is the essence of morals, this is because in morals it includes all acts of kindness (Amir, 1999: 34). While the concept of character in it only contains values and norms of humanity but does not pay attention to the concept of monotheism. It means, "And He taught Adam the names (objects) entirely, then conveyed them to the angels and then said:" Mention to me the names of these objects if you are really true people ". They replied: "Glory to Thou, We do not know anything other than what You have taught us; Verily You are the One Who Knows, Most Wise."

Here it is seen that the prophet Adam as. Remain subject to the orders of Allah Almighty. even though he was ordered by Allah SWT. to teach the angels. If he were uncivilized or felt he was superior then of course the prophet Adam, being a demon. So it is not certain that he will be given knowledge by Allah SWT., so adab will make it easier for someone to gain knowledge. Rasulullah saw. Said:

"My Lord taught me adab then He is the one who beautifies my manners." (HR. Al-'Askariy from Ali)

$\mathrm{Al}$ Zarkasiy commented on the hadith that the hadith is dhaif, even though the meaning contained in the hadith is authentic. Between adab and knowledge is a mutually supportive relationship, when someone is civilized, knowledge will come to that person. Ethics relates to human attitudes and behavior, whether this attitude must be done or not done by humans (Harahap, 2005, 27). Ethics can be divided into two, namely carrying out activities that are in accordance with good and responsible attitudes and behavior. Talking about academic ethics is related to comprehensive analysis with socio-historical aspects in academic culture. Academic ethics is a scientific activity in the academic world that is universally applicable (Budiman, 2004: 67). This means that academic ethics are social and cultural values in the higher education culture that have been agreed upon and their specific application in various academic activities. The purpose of academic ethics is to help direct and guide academic freedom so that it can be justified. The meaning of freedom here is the freedom of scientific thinkers in accordance with their fields of expertise in applying their knowledge with truth and obtained through the activities of scientific and logical methods.

In more detail, it is explained by Suparlan in Asari that academic freedom is a means of exploring the truth and publishing it by making the results of his research to be criticized with scientific concepts whether the findings are relevant to be rejected, corrected or acknowledged and strengthened (Asari, 2006: 167). One of the basic principles and foremost in the relationship between educators and students is respect, while students for educators and love. Therefore, in academia, the problems faced in society universally can be given solutions to intelligent problems. Meanwhile, tertiary institutions that are producers of academic 
personnel are expected to be able to produce good quality human resources professionally in science. The implementation of education to be successful and successful is strongly influenced by good academic ethics.

The achievement of an educational goal in accordance with the vision and mission of education effectively and directed, it is necessary to have a harmonious relationship between the relationship between educators and students. The achievement of an educational goal in accordance with the vision and mission of education in an effective and directed manner, it is necessary to have a harmonious relationship between the relationship between educators and students through academic ethics. Imam Alghazali explained that the formulation of student academic ethics that guides the education process is as follows (Mudzakkir, 2014: 115):

1. The need for the intention of worship in learning in order to get closer to Allah SWT. this will make the soul pure and good in character.

2. Putting the intention to heaven from over to the world.

3. Always be humble

4. Always focus on learning,

5. Studying the praiseworthy sciences both the hereafter and the world and leaving disgraceful knowledge.

6. Start learning from concrete things to abstract learning or from fardlu other science to fardlu kifayah science.

7. Complete the knowledge that has been studied completely and then continue other knowledge so that students have in-depth knowledge.

8. Using the scientific method to the knowledge studied so that science becomes objective in looking at a problem at hand.

9. The need for an understanding of pragmatic values for science.

10. Always follow the educator's advice

Based on the explanation above, it can be understood that the academic ethics of students must be implemented and obeyed so that there is a harmonious relationship between students and educators.

In Al-Qur'an, the concept of academic ethics is found; many solutions have been offered in building academic ethics. As an example like the verse below:

Meaning: As (we have perfected our favors to you) we have sent the Messenger among you who recite Our verses to you and sanctify you and teach you Al-Kitab and Al-Hikmah, and teach you what you do not know.

Based on the description of the above verse, it can be explained that Islam, is very concerned about ethics in education. The goal is to hope that Islamic education can build intelligence in various aspects of education. Intelligence is intellectual intelligence, emotional intelligence, and spiritual intelligence. This shows that Islamic education highly upholds academic ethics, with this ethics it is hoped that education will produce universally intelligent students both intellectually, emotionally, and spiritually. Islamic education is very serious about this, this can be seen with the concept of a regulated concept related to the rights and obligations of students and educators. Science in Islamic life is a very important and fundamental thing, but the most important thing is adab. With the rules that have been assigned to students and educators, it will have a good impact so that the goals of education can be achieved.

\subsection{Academic Degree Fever: From Intellectual Cheating To Public Duplication}

In the midst of this era of globalization, there is a battle of interests between ideologies in higher education, which means that there is a contestation between higher education based on academic values and corporate values (practically pragmatic). On the one hand, education plays a role in shaping public life while on moreover it only affirms the role of education in public life. Education itself acts as a vehicle to prepare students for certain forms of social, political, and cultural life (Postman, 1995: 89). So the goal is very clear that education is the center of educational institutions based on idealistic values. The problem is that when education is based on the values of market ideology, basic education is more concerned with humanistic ethical values and will end up being pragmatic materialistic values. This will change the face of education itself when the market ideology is dominant, then the meaning of education will change only to the extent of mastering basic techniques in the world of work (Nuryatno, 2008: 98).

This understanding is called technocratic rationality; in this understanding education only emphasizes pragmatic interests. This will have an impact on the loss of ethical-moral values and prioritize pragmatic values, so it is not surprising that many academicians carry out scientific activities instantly. In this case, the problem is when these graduate alumni devote themselves to the community by holding a bachelor's degree. Moreover, they are proud of the undergraduate degree but do not have the skills in their undergraduate field. This problem is a warning to the existence of higher education, which should be a social institution that 
forms an ethical democratic society. Thus, when a university is cultured with pragmatic life, at that time it will also lose its power of reasoning so that the existence of a university can no longer be a place for social change.

Basically, in social life in achieving progress, it is indicated that a person is able to meet the needs of a social group so that that person can contribute to society. Based on a review from Islam that knowledge is not sufficient for the provision of life, but that person must be accompanied by a height of adab and morals (Harahap, 2015: 33). If we look at it in today's society, it seems that this view has started to shift because if we see that the award is more to a degree than from one's knowledge. Some of the titles given to his name give confidence and appear quality in front of the community.

This has prompted some people to take academic degrees with a path that is not in accordance with the procedure. The procedure that was followed was what damaged the social order and academic ethics. It can be said that this degree was obtained based on the objective, namely degree fever. This can be seen at the time of the election of council members, if the title is not included it will give a feeling of confusion because the public is afraid that one of the candidates is not qualified.

\subsection{Analysis of Academic Ethics Violation Cases}

When viewed from various sources of media information, there are many acts of academic fraud that have been committed in various academic realms in Indonesia. It can be concluded temporarily that some tertiary institutions in Indonesia have not been able to produce superior and quality human resources. Although basically, academic cheating has certain reasons, it is an act that violates academic ethics. Actions that violate academic ethics are actions that facilitate all means without going through procedures to achieve the ultimate goals of higher education. As for activities that become academic violations that often occur, plagiarism and fake diplomas.

Islam is very concerned about ethics in education; the goal is that Islamic education can build intelligence in various aspects of education. Intelligence is intellectual intelligence, emotional intelligence, and spiritual intelligence. This shows that Islamic education highly upholds academic ethics, with this ethics it is hoped that education will produce universally intelligent students both intellectually, emotionally, and spiritually. Islamic education takes this very seriously; this can be seen by the conceptual arrangement that is regulated in relation to the rights and obligations of students and lecturers. Science in Islamic life is a very important and fundamental thing, but the most important thing is adab so that it will have a good impact so that the achievement of the goals of education itself is achieved.

So, in particular, it is fitting that students who attend education should actually carry their own titles rather than fake titles. The rise of fake diplomas in the community, this is due to low motivation to take the lecture process according to the procedure because it takes a long time. Moreover, because the falsification of certificates is damaging the image of educational institutions, the counterfeiters of certificates also destroy the mentality of the spirit of pursuing education for other generations. This happens because in the minds of science prosecutors, not even going to college can get a diploma, why are you tired of studying but it's the same as not going to college. At least the efforts to prevent this are as follows (Harahap, 2005: 45):

a. There needs to be government assertiveness in following up on this certificate forgery.

b. There must be cooperation and common perception from various parties so that any falsification of certificates must be dealt with.

c. Impose sanctions by increasing cooperation with law enforcement officials and investigating certificate falsification.

d. Providing media sharing information to the public and law enforcers so that people understand that falsification of certificates is an action that is detrimental to the future of the nation.

In the midst of this era of globalization, there is a battle of interests between ideologies in higher education, which means that there is a contestation between higher education based on academic values and corporate values (practically pragmatic). On the one hand, education plays a role in shaping public life while. Moreover, it only affirms the role of education in public life. Education itself acts as a vehicle to prepare students for certain forms of social, political, and cultural life. So the goal is very clear that education is the center of educational institutions based on idealistic values. The problem is that when education is based on the values of market ideology, basic education is more concerned with humanistic ethical values and will end up being pragmatic materialistic values. This will change the face of education itself when the market ideology is dominant, then the meaning of education will change only to the extent of mastering basic techniques in the world of work.

This understanding is called technocratic rationality; in this understanding education only emphasizes pragmatic interests. This will have an impact on the loss of ethical-moral values and prioritize pragmatic 
values, so it is not surprising that many academicians carry out scientific activities instantly. In this case, the problem is when these graduate alumni devote themselves to the community by holding a bachelor's degree. Moreover, they are proud of the undergraduate degree but do not have the skills in their undergraduate field. This problem is a warning to the existence of higher education, which should be a social institution that forms an ethical democratic society. Thus, when a university is cultured with pragmatic life, at that time it will also lose its power of reasoning so that the existence of a university can no longer be a place for social change. This is what is strictly guarded by STIT Al-Hikmah Tebing Tinggi so that the face of education is not scratched by the actions of a few people.

For example, such as the case of plagiarism that one of the ways to obtain scientific works on behalf of oneself. Scientific work is said to have the highest value as originality or authenticity. The meaning of originality here is that in addition to the ideas and notions of knowledge conveyed through scientific work, it is also more emphasis on honesty in suggesting the reference source of the writing. In this case, all members of the academic community must adhere to the academic ethics that apply to a university which is one form of building character. Formally, action against plagiarism perpetrators is a violation of the law, because this act is an act of theft against the property of others. If this action occurs, the perpetrator may be subject to criminal law. The act of plagiarism that has developed must be anticipated as soon as possible because it is against character development and it is feared that it will become a culture inherent in society. Plagiarism by a person shows that that person is a perpetrator who does everything easily and the level of originality of his work is low.

It has been previously mentioned that there is a phenomenon in the society of degree fever, sometimes the title is obtained from a path that is in accordance with the path of education. What is incompatible with this is the occurrence of a phenomenon related to fake diplomas that denote one's title. Obtaining this fake diploma is generally not only ordinary people who do it, but also public officials. Many factors led to the falsification of these certificates, including social strata, to fulfill the economy and position, lack of understanding of religion, and weak educational administration. Sometimes the problem of weak educational administration is something that makes the public think it is easy to get a diploma. If the education administration is good, then fake certificates will be difficult to obtain or will prevent certificate falsification.

Based on the violations committed, there are two groups of ethical violations, namely (Syafaruddin, 2016: 78), violations that are committed deliberately, this means that the perpetrator of fraud knows that his act is a violation and should be sanctioned. Next is a violation that is committed accidentally, namely a violation that is committed that the violation is not known to the boundaries of academic ethics itself. Moreover, this phenomenon is also caused by two things, namely (Azizy, 2004: 45), a person's lack of appreciation for the work made by other people. Next is the inability of someone to write and use written documents as a guide. The thing that is emphasized here is that the empirical perspective on ethical violations is not to defame other people, but ourselves who violate these regulations.

Based on the explanation above, it can be understood that in addition to obtaining an academic degree outside of procedure, according to the procedure, if you commit plagiarism it can also be said to be a violation of academic ethics. Each academic actor, such as students, is demanded to always be active in society so that academic actors have an existence. With the existence of students as academic actors, that their existence in society always provides solutions to the best of their abilities in solving problems. So when you appear in the community, don't have very limited abilities in your field, because the knowledge you have when you are in higher education must be applied through community service.

Basically, honesty is a word, action, and action that is strived to be in line with or with these three things which always get the trust from other than him. Basically, every educational activity, both in conceptualizing educational theories and in operational techniques, must have strong foundations and have academic ethics guidelines. In order for these educational values to be implemented optimally, we need a rule that can control the process of implementing education; this is what is called academic ethics. Ethics is something that is related to social and cultural values that have become an agreement in a community as norms and rules that are obeyed collectively, this ethic is not always the same in all societies.

Students who graduate should be students who are indeed following predetermined learning, not stealth students. The emphasis on the value of honesty in academic ethics consists of two things, namely in writing scientific papers and completing studies. Students as academic actors in idealism as agents of change in social society must have a character as forged in higher education. Do not let intellectual crimes in the form of plagiarism become a culture for some groups of people? One of the causes of this plagiarism is not having the ability to carry out scientific activities or wanting to finish quickly without going through procedures. The solution to this problem is that it must be done systematically and comprehensively and requires commitment from various parties to fix the problem.

With regard to ethics, it cannot be separated from the participation of the important role of Islamic 
Education. In this connection, education must be able to foster morals through the development of academic values, this means being contrary to the concept of social pragmatism and material achievement alone. So the task of higher education is highly emphasized in this case, because the products produced by universities are agents of change. Therefore, alumni of Islamic tertiary institutions must become a forum for making changes based on Islamic values. The values of academic ethics must be held and applied in every academic person ideally in the midst of the challenges of today's pragmatism. This is where it is important to instill the values of honesty towards students in the learning process; if these values are accustomed to students then by themselves students will be planted with the values of moral education. Adab is very closely related to morals, adab is all praiseworthy deeds and deeds that become a person's character or habit, thus between adab and morals is something that cannot be separated.

Students will open their minds if they are accustomed to scientific methods which are indeed their own, not plagiarism. If students live with the concept of plagiarism, the flow of their scientific mindset will be frozen. Academic freedom is a means of digging for the truth and publishing it by making the results of the research criticized with scientific concepts whether the findings are relevant to be rejected, corrected or acknowledged, and strengthened. One of the basic principles and foremost in the relationship between educators and students is respect, while students for educators and love. Therefore, in academia, the problems faced in society universally can be given solutions to intelligent problems. Meanwhile, tertiary institutions that are producers of academic personnel are expected to be able to produce good quality human resources professionally in science. The implementation of education to be successful and successful is strongly influenced by good academic ethics. To achieve a goal of Islamic higher education, especially in accordance with the vision and mission of education in an effective and directed manner, it is necessary to have a harmonious relationship between the relationship between educators and students through academic ethics.

\subsection{The Final Analysis: Causes and Solutions}

Students as academic actors in idealism as agents of change in social society must have a character as forged in higher education. Do not let intellectual crimes in the form of plagiarism become a culture for some groups of people? One of the causes of this plagiarism is not having the ability to carry out scientific activities or wanting to finish quickly without going through procedures. The solution to this problem is that it must be done systematically and comprehensively and requires commitment from various parties to fix the problem.

Another example is the proliferation of fake diplomas; this is because of the low motivation to take the lecture process in accordance with the procedure because it takes a long time. Moreover, because the falsification of certificates is damaging the image of educational institutions, the counterfeiters of certificates also destroy the mentality of the spirit of pursuing education for other generations. This happens because in the minds of science prosecutors, not even going to college can get a diploma, why are you tired of studying but it's the same as not going to college. At least the efforts to prevent this are as follows (Harahap, 2005: 45):

a. There needs to be government assertiveness in following up on this certificate forgery.

b. There must be cooperation and common perception from various parties so that any falsification of certificates must be dealt with.

c. Impose sanctions by increasing cooperation with law enforcement officials and investigating certificate falsification.

d. Providing media sharing information to the public and law enforcers so that people understand that falsification of certificates is an action that is detrimental to the future of the nation.

The concept of ethics in academia is widely described in the Koran, this can be seen through meanings that indicate ethics. Quoted from the wise words of B.J. Habibie said that in developing science and technology, the most urgent thing needed is that a scientist must have credibility and predictability insights. A lot of money, if not credible, then the money is not clear where it goes if it is credible, then with little money, the money will double inline knocking on your door (Kartanegara, 2005: 48). To change one's perspective, one must not only teach ethics to someone as something separate from the research process. This means that research activities are not related to academic achievement, the most important and urgent thing is how to find solutions to failures. So research activities are activities that are carried out not only during academic activities but also outside academics. But even so, academic ethics must also be upheld because honesty is the most important thing to get results without harming others. The point is the question of mastery of the technique, because with the development of thinking technique mastery must be.

Basically, honesty is a word, action, and action that is strived to be in line with or with these three things which always get the trust from other than him. Basically, every educational activity, both in 
conceptualizing educational theories and in operational techniques, must have strong foundations and have academic ethics guidelines. In order for these educational values to be implemented optimally, we need a rule that can control the process of implementing education; this is what is called academic ethics. Ethics is something that is related to social and cultural values that have become an agreement in a community as norms and rules that are obeyed collectively, this ethic is not always the same in all societies. Students who graduate should be students who are indeed following predetermined learning, not stealth students. The emphasis on the value of honesty in academic ethics consists of two things, namely in writing scientific papers and completing studies. Students as academic actors in idealism as agents of change in social society must have character as forged in higher education. While the concept of character in it only contains values and norms of humanity but does not pay attention to the concept of monotheism.

At least in responding to this in giving birth to generations through educational institutions, it determines the following matters:

1. Intending worship in every learning academic process.

2. Prospects for ukhrawi.

3. Always tawadu '

Based on the explanation above, it can be understood that the cultivation of the value of honesty and academic ethics must be carried out so that there is a harmonious relationship between students and lecturers. Islam is very concerned about ethics in education; the goal is that Islamic education can build intelligence in various aspects of education. Science in Islamic life is a very important and fundamental thing, but the most important thing is adab so that it will have a good impact so that the achievement of the goals of education itself is achieved. In the midst of this globalization era, there is a battle of interests between ideologies in higher education; in this understanding education only emphasizes pragmatic interests. This will have an impact on the loss of ethical-moral values and prioritize pragmatic values, so it is not surprising that many academicians carry out scientific activities instantly. In this case, the problem is when these graduate alumni devote themselves to the community by holding a bachelor's degree. Moreover, they are proud of the undergraduate degree but do not have the skills in their undergraduate field.

Basically, in social life in achieving progress, it is indicated that a person is able to meet the needs of a social group so that that person can contribute to society. Regardless of a person's intention, one of the efforts made by the community to obtain an education is to get a scholarship so that it gets recognition from the community about their social status. Based on the review from Islam that knowledge is not sufficient for the provision in living life but that person must be accompanied by a height of manners and morals. If we look at it in today's society, it seems that this view has started to shift because if we see that the award is more to a degree than from one's knowledge.

To change one's viewpoint, you must not only teach ethics to someone as something separate from the research process. This means that research activities are not related to academic achievement, the most important and urgent thing is how to find solutions to failures. So research activities are activities that are carried out not only during academic activities but also outside academics. But even so, academic ethics must also be upheld because honesty is the most important thing to get results without harming others. The point is the question of mastery of the technique, because with the development of thinking technique mastery must be. The aim of the research is to have mastery in the scientific field and the methods that support that science.

\section{Conclusion}

The academic world is a forum whose process always follows academic ethics through scientific activities. Thus academic ethics is essentially a scientific activity that takes place in higher education which includes universal and developing activities. Higher education institutions must be prepared to accept criticism with mutual respect and not engage in discriminatory activities. Violations committed in academic ethics are something that damages and tarnishes the world of education. In order for these educational values to be implemented optimally, we need a rule that can control the process of implementing education; this is what is called academic ethics. The emphasis on the value of honesty in academic ethics consists of two things, namely in writing scientific papers and completing studies. Therefore, it is demanded that every education actor is systematic and comprehensive and requires commitment from various parties to fix problems in education.

\section{References}

Amir, Miftah, (1999). Ethics of Mass Communication in Islamic View, Jakarta: Logos. 
Azizy, A. Qodri A, (2003). Religious Education for Building Social Ethics, Semarang: Various Sciences.

Asari, Hasan, (2006). Revealing History of Finding 'Ibrah: A Brief History of Social-Intellectual Muslim Classics, Bandung: Citapustaka Media

Budiman, Fransisco Hardi, (2004). Ideological Criticism: Uncovering the Interests behind Collaborative Knowledge Jurgen Habermas, Yogyakarta: Good Books.

Harahap, Syahrin, (2015). Islam and Modernity: From Modernization Theory to Upholding Modern Piety, Jakarta: Kencana.

Harahap, Syahrin. (2005). Enforcement of Academic Morals: Inside and Outside the Campus, Jakarta: RajaGrafindo Persada.

Jusuf Mudzakkir and Abdul Mujib, (2014). Islamic Education (Jakarta: Kencana,

Kartanehara, Mulyadhi, (2005). Breaking the Deadline: Panorama of Islamic Philosophy Bandung: Mizan.

Nuryatno, M. Agus. (2008). The School of Critical Education. Yogyakarta: Resist Book.

Postman, Neil. (1995). The End of Education: Redefining the Value of School. New York: Alfred A. Knopf. 